\title{
A Case of Myofibroblastic Sarcoma Originating in the Buccal Mucosa
}

\author{
In Buhm Lee ${ }^{\mathbb{D}}$, Hye Soo Kim, Jin Lee ${ }^{\mathbb{D}}$, and Sang Hyuk Lee ${ }^{\mathbb{B}}$ \\ Department of Otorhinolaryngology-Head and Neck Surgery, Kangbuk Samsung Hospital, Sungkyunkwan University School of Medicine, \\ Seoul, Korea
}

\section{볼 점막에서 발생한 근섬유모세포 육종 1예}

이인범 · 김혜수 · 이 진 · 이상혁

성균관대학교 의과대학 강북삼성병원 이비인후과학교실

\author{
Received April 24, 2020 \\ Revised May 21, 2020 \\ Accepted June 9, 2020 \\ Address for correspondence \\ Sang Hyuk Lee, MD, PhD \\ Department of Otorhinolaryngology- \\ Head and Neck Surgery, \\ Kangbuk Samsung Hospital, \\ Sungkyunkwan University \\ School of Medicine, \\ 29 Saemunan-ro, Jongno-gu, \\ Seoul 03181, Korea \\ Tel $+82-2-2001-2269$ \\ Fax $+82-2-2001-2273$ \\ E-mail entlsh@hanmail.ne
}

\begin{abstract}
Myofibroblastic sarcoma (MS) is an extremely rare form of head and neck tumor that originates from mesenchymal cells. Myofibroblasts are mesenchymal spindle cells that share the features of fibroblasts and smooth muscle cells. Radiologic examinations such as CT and MRI are useful first-line diagnostic tools for differential diagnosis. Complete surgical excision is recommended for successful treatment. MS can be classified as low, intermediate or high grade considering its histological differentiation and time course. Intermediate and high grade MS are known to be related to local recurrence or distant metastasis. With a review of literature, we report a case of MS arising from the left buccal mucosa in a 56-year-old male who complained of a painless left buccal mass. The patient was successfully treated by margin-free excision and the pathologic findings concluded as intermediate grade without any complication. There was no recurrence observed for two years since the surgery.
\end{abstract}

Korean J Otorhinolaryngol-Head Neck Surg 2021;64(5):359-64

Key Words Fibroblasts · Myoblasts · Myofibroblastic sarcomas · Myofibroblasts $\cdot$ Sarcoma.

서 론

근섬유모세포 육종(myofibroblastic sarcoma, MS)은 근 섬유모세포에서 기원한 악성종양으로 몸의 어떤 부위에서도 발생할 수 있으나 하악골, 부비동, 후두, 두개저 등의 구강 내 에서 호발하며 가장 흔하게 나타나는 부위는 혀로 알려져 있 다.,2) 전체 두경부 종양의 $80 \%$ 이상이 편평상피세포에서 기 원하고 중배엽세포 기원의 간엽세포성(mesenchymal cell) 종양의 발생 빈도는 매우 낮은 편이며 이 중에서도 근섬유모 세포 육종의 빈도는 극히 낮다. ${ }^{1,3)}$ 소아부터 노인까지 전 연령 대에서 발생할 수 있으나 40 50대에서 가장 호발하며 2,4) 여

This is an Open Access article distributed under the terms of the Creative Commons Attribution Non-Commercial License (https://creativecommons.org/licenses/by-nc/4.0) which permits unrestricted non-commercial use, distribution, and reproduction in any medium, provided the original work is properly cited.
성보다는 남성에서 발병률이 높다.,5) 근섬유모세포 육종은 종양세포의 분화도 및 시간 경과에 따라 저등급(low grade), 중등급(intermediate grade), 고등급(high grade)로 분류된 다. ${ }^{3)}$ 중등급, 고등급 군에서는 저등급 군에 비해 원격전이의 가능성이 높은 것으로 알려져 있으며 저등급 군에서는 원격 전이보다는 국소재발이 흔하다.,5,6) 육종의 발생 원인은 아직 명확하지 않으나, 유전적 요인과 환경적 요인의 상호작용이 영향을 미칠 것으로 알려져 있다. ${ }^{3)}$

근섬유모세포 육종은 형태학적으로 섬유모세포 및 평활 근세포와 유사하므로 쉽게 오진할 수 있어 정확한 감별진단 이 중요하며 주로 섬유육종, 평활근육종, 섬유종증, 결절근막 염, 악성섬유조직구종, 악성 말초신경초종, 염증성 근섬유모 세포 종양 등과의 감별이 필요하다.,7,8) 근섬유모세포 육종은 발생 빈도가 낮고 임상적 특징 또한 두드러지지 않아 매우 
드물게 보고되고 있다. ${ }^{1-3,9)}$ 고찰상 현재까지 보고된 근섬유모 세포 육종의 증례 중에서 볼 점막 부위에 발생한 경우는 국 내에서 아직 보고된 바가 없다.

저자들은 좌측 볼 점막 부위의 무통성 종물을 주소로 내 원한 56세 남자에서 수술 전 시행한 조직검사로 악성 간엽성 육종(malignant mesenchymal sarcoma) 혹은 방추상 세포 편평세포암(spindle cell squamous cell carcinoma)으로 확 인되어 추가적인 영상의학적 검사를 통한 수술 범위 결정 후 진단 및 치료 목적으로 경구강 광범위 절제술을 시행하여 좌측 근섬유모세포 육종으로 확진된 1예를 치험하였기에 이 를 문헌 고찰과 함께 보고하는 바이다.

\section{증 례}

56세 남자 환자가 내원 3주 전 좌측 볼 점막 부위에 발생한 무통성 종물을 주소로 내원하였다. 평소 알코올성 간경화 않 고 지내던 자로, 이학적 검사 시 좌측 볼 점막의 $2.5 \mathrm{~cm}$ 크기 의 타원형 모양의 단발성 종괴가 보였으며(Fig. 1A), 촉진 시 에 움직이며 비교적 단단하게 만져지고, 통증 및 압통은 동 반하지 않았다. 이에 섬유종(fibroma), 육아종(granuloma) 등을 의심하여 병변의 일부를 절제하여 $1.5 \times 1.0 \mathrm{~cm}$ 크기의 비교적 잘 구획된 회백색의 검체를 채취하였으며 조직검사 를 시행하였다. 조직검사 소견에서 악성 간엽성 육종 또는 방 추상 세포 편평세포암으로 확인되었다.

병변의 위치와 깊이, 주변 조직으로의 침범 정도를 보다 정 확하게 평가하기 위해 수술 전 시행한 경부 컴퓨터단층촬영

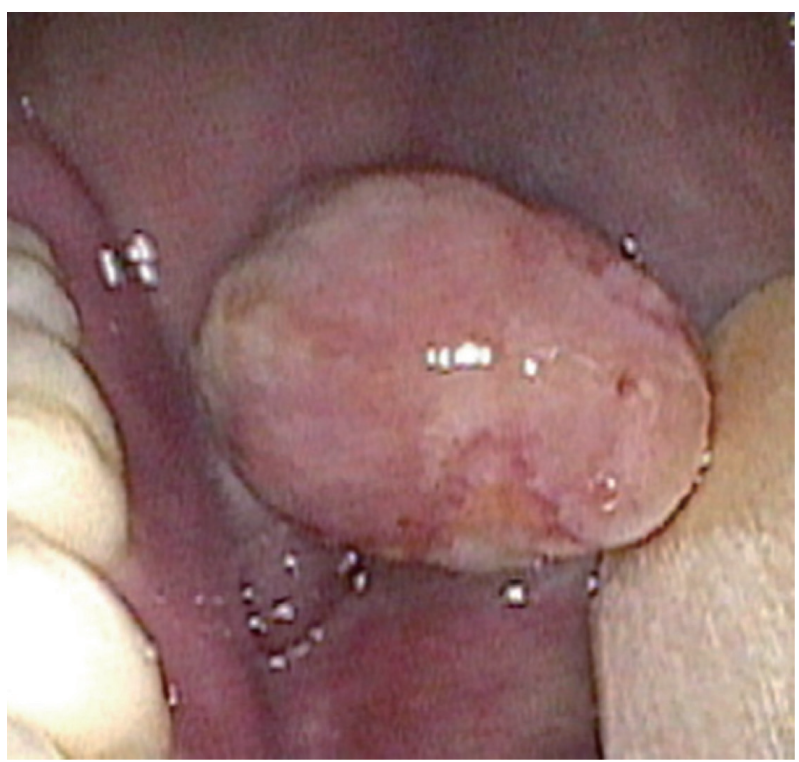

Fig. 1. Preoperative photograph. Gross findings of preoperative state of left buccal mucosa.
(CT) 및 경부 자기공명영상(MRI) 검사에서 좌측 볼 점막 부 근에 $2.1 \times 0.8 \mathrm{~cm}$ 크기의 다소 경계가 불명확하고 불균질한 음영을 보이는 종물이 관찰되었다. CT 검사에서 하악골에 인 접한 소견이 보였으나 골 침범의 가능성은 낮아 보였고, MRI 검사를 통해 협근(buccinator muscle)을 비롯한 주변으로의 침범 정도를 확인하고자 하였으나 불균질한 신호강도를 보여 주변 연조직과의 침범 여부를 가늠하기에는 다소 제한점이 있었다(Fig. 2A-D). 원격전이 여부를 확인하기 위해 PETCT를 시행하였으며 좌측 볼 점막의 병변에서 높은 흡수 섭 취를 보여 malignancy 가능성을 시사하였으며, 좌측 경부 림프절 2구역에서 경도의 흡수 섭취를 보였으나 반응성 림프 절 소견으로 의심되었다(Fig. 2E and F). 수술 전 시행한 혈 액검사, 심전도 및 소변검사에서 모두 정상 범위 소견을 보였 으며, 흥부 방사선 검사에서 좌측 늑막의 농밀화 혹은 좌측 흥수 소견을 보여 호흡기내과 전문의의 협의진료하 수술적 치료를 시행하기에 문제가 없음을 최종 확인하였다.

저자들은 이상의 결과로 암 조직의 광범위한 절제를 위하 여 진단 및 치료의 목적으로 경구강 광범위 절제술을 계획하 였다. 전신마취하에 경구강 접근하 좌측 볼점막에 $1.5 \times 1.0$ $\mathrm{cm}$ 크기의 종물이 관찰되었다. 종물은 협근으로의 침범 없이 비교적 경계가 명확하였고 주변과의 유착 없이 잘 박리되었 다. 이에 저자들은 병변으로부터 $1.0 \mathrm{~cm}$ 안전역을 확보하고 자유면 절제를 시행하였다(Fig. 3). 이후 점막하 조직 및 점 막 표면을 일차 봉합하였고 수술을 종료하였다.

수술 후 확인된 병리 소견상 방추상세포 다발로 이뤄진 섬 유육종성 세포가 V자 배열(herringbone pattern)을 이루고 있었으며, 약 $2.0 \times 1.5 \times 1.0 \mathrm{~cm}$ 크기를 형성하는 중등급의 근 섬유모세포 육종(MS) 소견을 보였다(Fig. 4A and B). 면역조 직화학 검사에서 desmin, smooth muscle actin, vimentin 양성 소견을 보였으며 $\mathrm{CKAE} 1 / 3, \mathrm{~S} 100$ 에서는 특이소견을 보 이지 않았다(Fig. 4). CD34, CD31, melan A, c-kit, and epithelial membrane antigen에서는 모두 음성 소견을 보였다.

환자는 수술 후 특별한 합병증을 보이지 않았고 수술 후 2년 간의 추적 검사에서 재발의 흔적이나 혈류 장애 및 기능적 이상 소견은 관찰되지 않았다.

\section{고 찰}

근섬유모세포 육종은 중배엽성 세포에서 기원한 매우 드 문 형태의 육종으로, 섬유모세포와 평활근세포의 특성을 동 시에 가지는 것이 특징이다.,10) 골, 연골, 근육, 섬유세포, 혈 관, 지방, 신경조직 등 인체의 거의 모든 조직에서 발생할 수 있으며, 그 중 두경부에서 가장 호발한다. ${ }^{1,3)}$ 근섬유모세포를 
종양의 실질적인 구성 세포로 볼 것인지에 대하여 오랜 논쟁 이 있었고 몇몇 학자들은 근섬유모세포 종양의 존재를 초기 에는 인정하지 않았으나 2002년 세계보건기구(World Health Organization)에서 발표한 뼈와 연조직 종양 분류(classifi- cation of bone and soft tissue tumors)에서 저등급의 근섬유 모세포 육종을 독립적인 새로운 질병군으로 분류함에 따라 현재는 객관적으로 실존하는 종양으로서 인정받게 되었다. ${ }^{4}$

국소적인 무통성 종물이 가장 흔한 증상으로, 4주에서 72 개
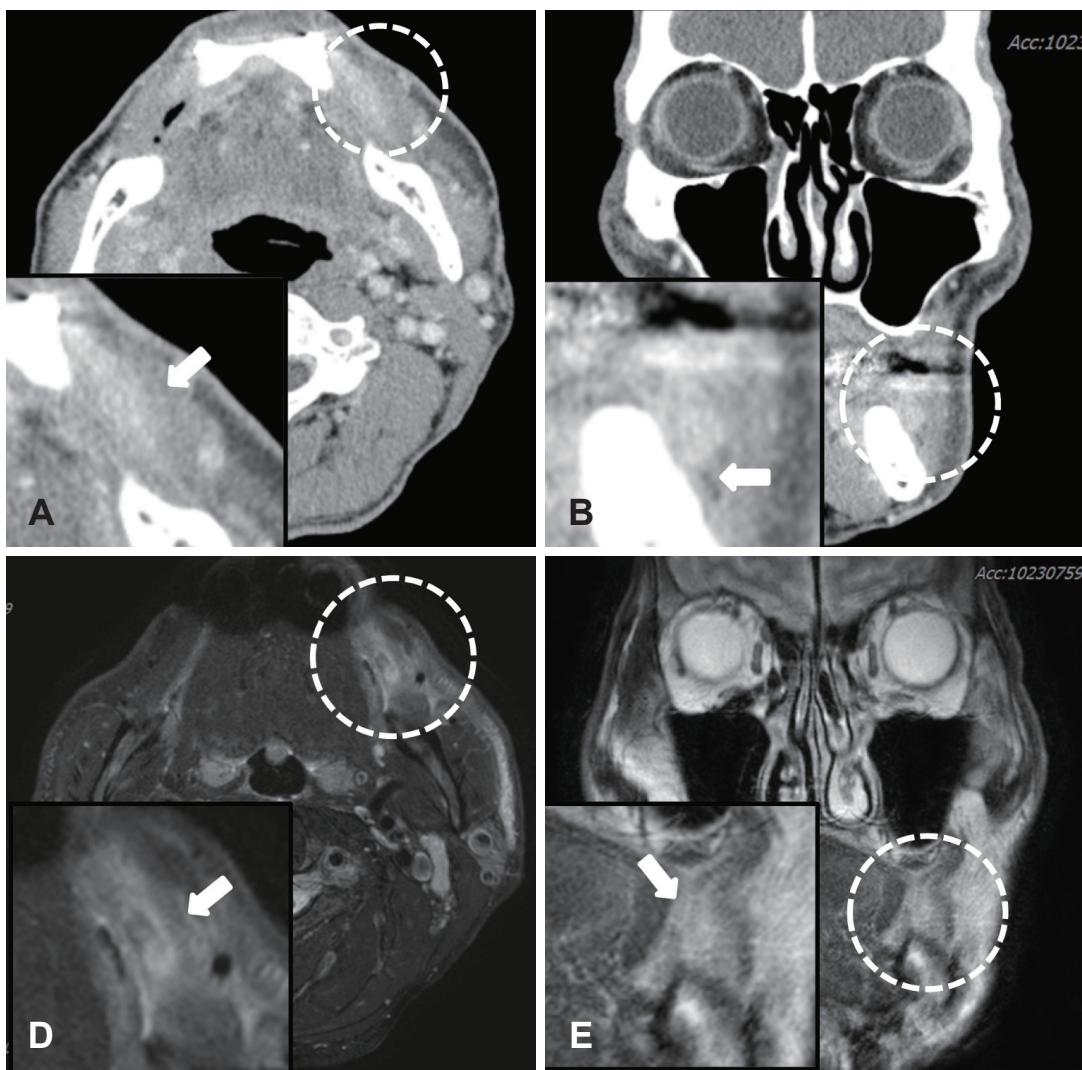

C
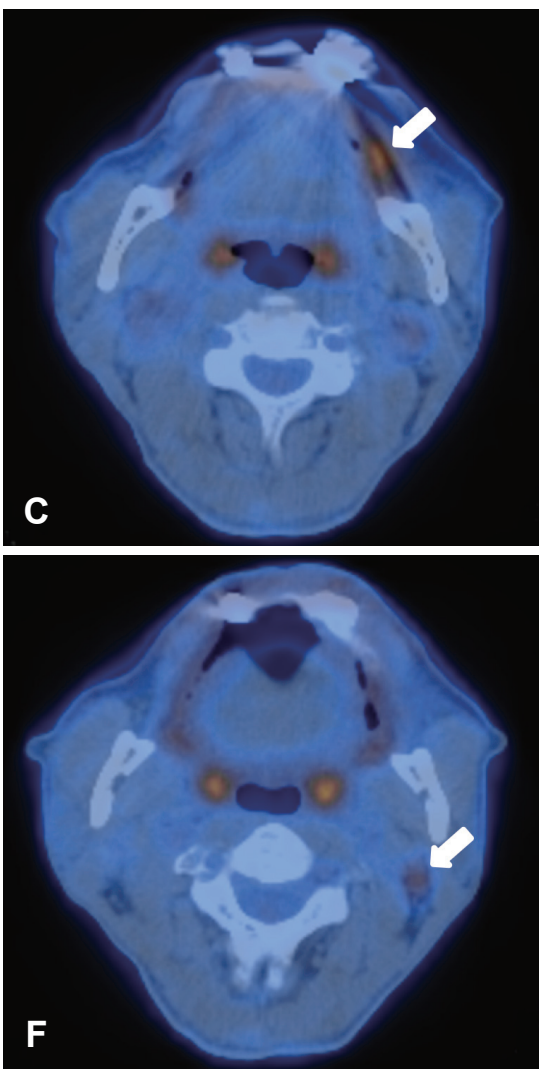

Fig. 2. Preoperative diagnostic imaging. Preoperative axial, coronal view of enhanced neck CT \& neck MRI scan shows the ovoid, ill defined, measuring $2.1 \mathrm{~cm}$ in longest dimension, heterogenous enhanced mass (arrow) in the left buccal area (A-D). Preoperative axial view of PET-CT scan shows hypermetabolic mass in left buccal mucosa (arrow above) seemed to be malignancy more likely and mild hypermetabolic LN in left neck level II area (arrow below) seemed to be reactive lesion (E, F).
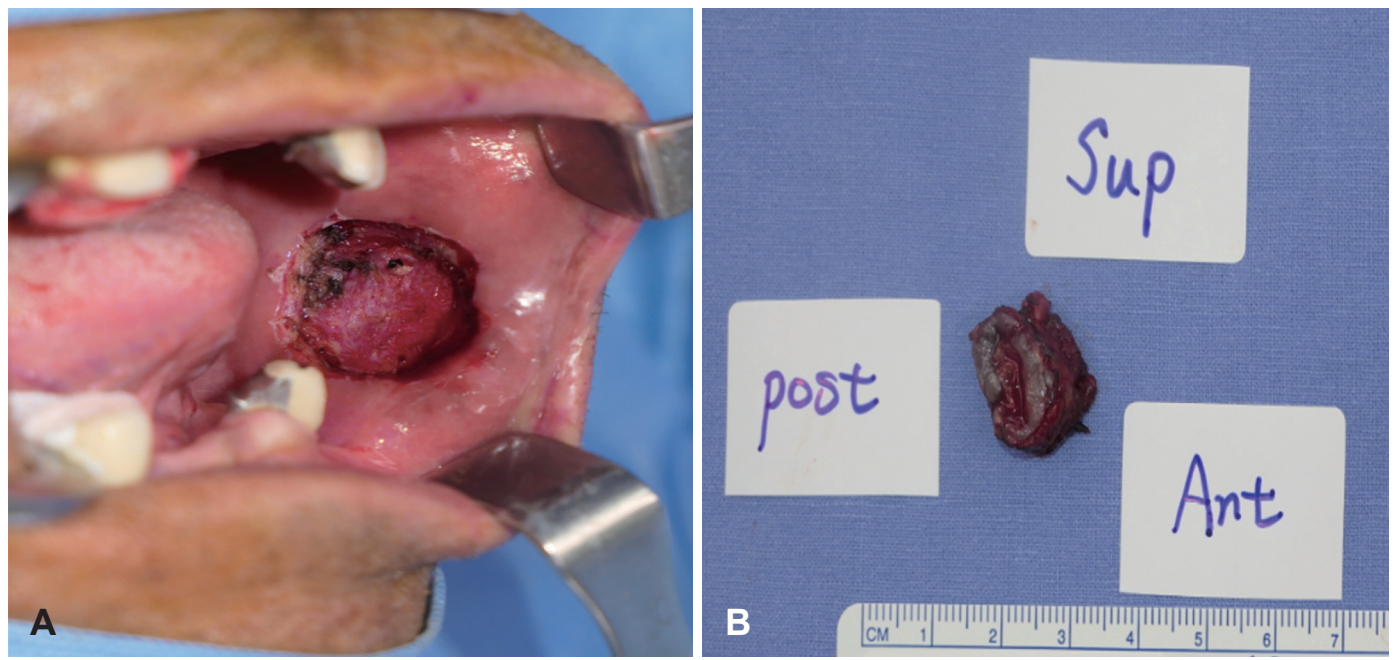

Fig. 3. Intraoperative photograph. Gross findings of post operation appearance of buccal mucosa (A). Intraoperative photograph shows $2.0 \times 2.0 \mathrm{~cm}$ sized well lobulated, firm mass in the buccal mucosa (B). 

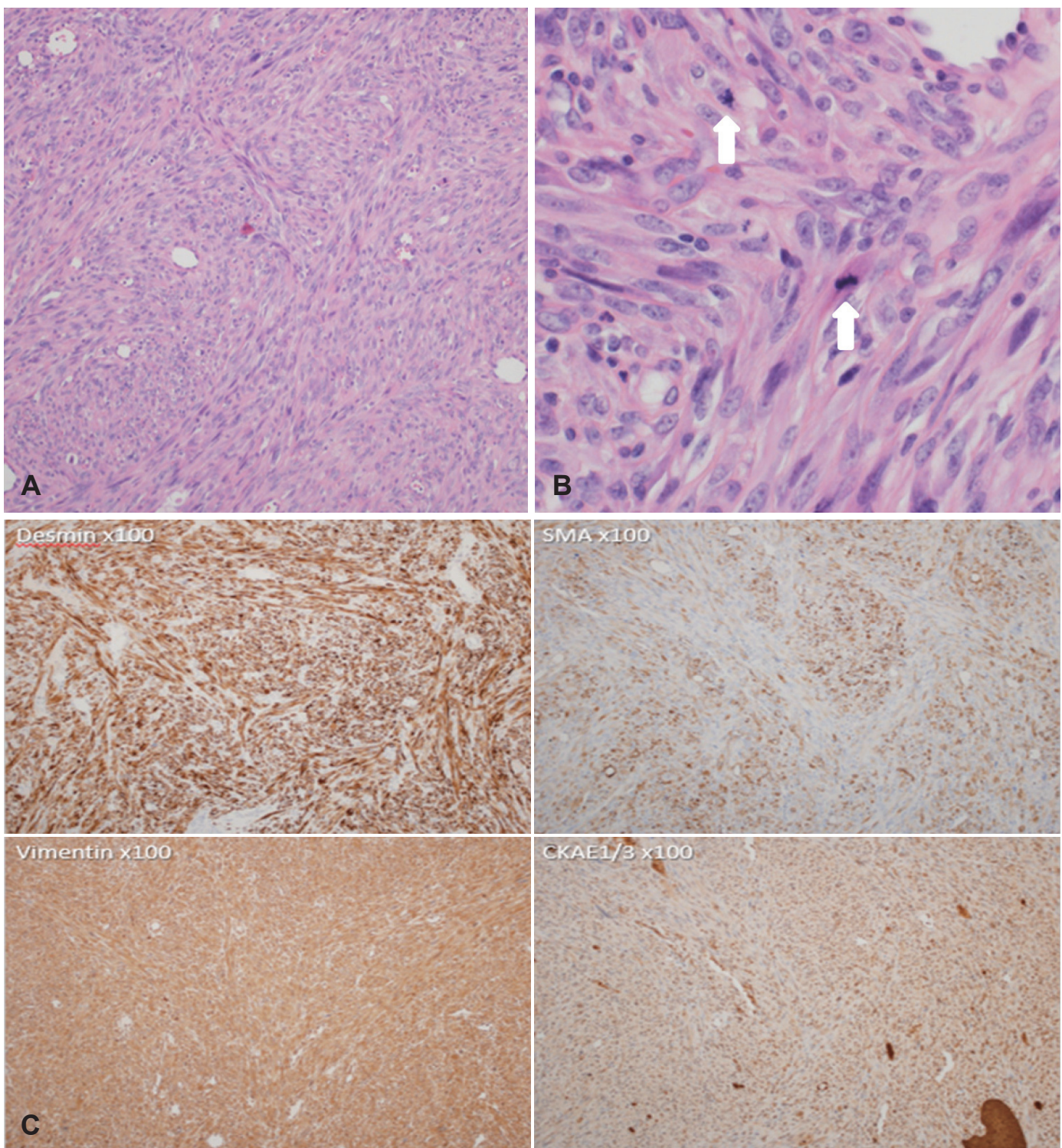

Fig. 4. Pathologic finding. Cellular, fibrosarcoma-like lesion composed of fascicles of spindle cells, arranged in herringbone pattern (H\&E stain, $\times 100)(A)$. Fusiform nuclei with evenly distributed chromatin, indentations, and small nucleoli. There is moderate amount of pale eosinophilic cytoplasm. Frequent mitotic figures (arrow) are present (H\&E stain, $\times 400)(B)$. Immunohistochemistry for desmin, SMA, and vimentin is positive for tumor cells. CKAE1/3 and S100 show nonspecific expression (C). H\&E: hematoxylin and eosin.

월(평균 13 개월)에 걸쳐 점진적으로 커지는 양상을 보인다.) 유모세포는 상처나 염증조직의 회복 과정에서 일시적으로 보 일 수 있으나 회복이 종결되면 보통 세포자멸사를 통해 사라 지는데, 바로 이 과정에서 문제가 생기면 악성종양세포로 분 화할 수 있는 것으로 알려져 있다.,7) 아직 많은 연구가 진행 되지 않았기에 섬유모세포의 종양세포로의 전환 과정은 정 확히 밝혀지지 않은 상태이다. ${ }^{5,10)}$

정확한 병변의 위치 및 침범 정도의 평가를 위해 영상학적 진단이 도움이 될 수 있다. 본 증례에서는 경부 전산화단층 컴 퓨터촬영(CT)과 자기공명영상 촬영(MRI)을 시행하였다. 조영 증강 CT에서는 주로 비균질한 조영 증강(heterogeneous en- hancement) 소견을 보이며 MRI에서는 T1WI에서 균질한 저 강도 신호(homogeneous and hypo-intense signal)를 보이고 T2WI에서 고강도 신호(hyper-intense signal)를 보이는 것 으로 알려져 있다. ${ }^{11)} \mathrm{CT}$ 에서는 주변을 둘러싼 근육 조직과 비교하여 다소 불명확한 경계의 비균질한 고음영 또는 저음 영 소견을 보인다. 특히 골 조직에서 발생한 근섬유모세포 육 종의 경우 광범위한 석회화 또는 골화의 소견이 동반될 수 있 다. ${ }^{11)} \mathrm{MRI}$ 에서는 T1WI 소견으로 균질한 동신호 혹은 고신호 강도를 보일 수 있고, T2WI 소견으로 균질 혹은 비균질한 고 신호 강도를 보일 수 있다. 조영증강 MRI 검사를 시행하면 균질 혹은 비균질한 조영증강 소견을 관찰할 수 있으며 간혹 
테두리 조영증강 소견이 보일 수 있다. ${ }^{11}$ 수술 전 $\mathrm{CT}, \mathrm{MRI}$ 촬 영은 진단에 필수적인 도구이지만 근섬유모세포 육종에서는 다른 질환과의 감별점으로 제안될 만한 특징적인 소견은 보 이지 않는다. 본 증례 또한 상기 영상 검사만으로 근섬유모 세포 육종을 진단하기에는 어려움이 있었다. 이에 향후 두경 부 종양의 진단 및 평가에 있어 보다 새롭고 혁신적인 영상 진단 기법에 대한 필요성이 더욱 강조되고 있다.

최근 연구개발 중인 분자영상의학(In vivo molecular imaging)은 종양의 임상진단에 혁신적이며 핵심이 되는 영상기 법이다. 이 새로운 진단 도구는 세포 수준, 분자 수준의 정보 를 수집하여 종양의 수술 전 진단, 치료, 예후평가에 도움을 줄 수 있다. 방법론으로 3 가지의 흥미로운 기술이 제안되는데, 첫째는 방사성 분자 표지자를 이용하여 양전자방출단층촬영 (PET-CT)과 단일광자 단층촬영(single-photon emission $\mathrm{CT})$ 를 통해 분포와 운동역학을 측정하는 핵의학적 영상 기법 (nuclear medical imaging)이다. 방사성 동위원소는 크게 두 그룹으로 나눌 수 있는데 하나는 생물체에 작용하는 성분으 로 구성된 ${ }^{11} \mathrm{C},{ }^{15} \mathrm{O}$ 등이고 다른 하나는 생물체에 작용하지 않는 성분으로 구성된 ${ }^{18} \mathrm{~F},{ }^{123} \mathrm{I},{ }^{99} \mathrm{mTc}$ 등이다. 전자의 경우는 짧은 반감기로 인하여 단 기간 내에 결과를 얻어내야 한다는 점이 중요하고 후자의 경우는 분자의 구조가 중요한데 이는 외부 물질 유입으로 인한 체내의 생리학적, 화학적 변화들이 일으킬 수 있기 때문이다. 대표적으로 많이 사용되는 ${ }^{18} \mathrm{~F}$-표 지된 아미노산은 신경교종, 신경내분비종양, 전립선암, 유방 암 등에서 아미노산 대사의 상승을 보여준다. ${ }^{12)}$ 두 번째로 광 학 분자 영상 기법(optical molecular imaging)은 형광 표지 자의 분포와 운동역학을 분석해 실시간 영상을 만들어낸 다. ${ }^{12)}$ 이것은 비교적 저렴한 비용으로 고해상도의 영상을 얻 어낼 수 있다는 장점이 있지만 영상의 영역이 체표면에 국한 된다는 제한점이 있다. 마지막으로 광음향 영상 기법(photoacoustic imaging)은 심부 조직의 섬세하고 세밀한 광음향 신 호를 탐지하여 영상을 구현한다. ${ }^{12)}$ 친수성 중합체인 polyoxazoline을 indocyanine green(ICG)와 결합시켜 광음향 신호 의 표지자로 이용하는 방법으로 결합 정도에 따라 신호 강도 가 달라져 좋은 해상력의 영상을 얻어낼 수 있으며 심부조직 의 영상까지 얻을 수 있다는 장점이 있다. ${ }^{12)}$ 비록 현재의 기 술적 한계로 인해 본 증례에서는 상기의 영상 기법을 적용하 지 못했으나 미래에는 분자 영상의학이 좋은 진단 기법으로 활용될 수 있을 것이다.

위와 같은 영상 검사들은 수술 전 병변의 감별진단에 도움 이 될 수 있으며 최종적인 진단을 위해서는 조직학적 검사가 필요하다. 특징적인 병리학적 소견으로 저등급의 경우 비정 형 핵을 보이는 경우가 적으며 유사분열세포의 비율이 낮으
나, 중-고등급의 경우 비정형 핵을 보이는 경우가 많고 과다 염색성 구조를 가지며, 명백한 유사분열성 특징을 나타낸다.) 프랑스의 암 센터 연합조직인 Fédération Nationale des Centres de Lutte le Cancer(FNCLCC)의 연조직 종양 분류 에 따르면 등급은 유사분열 정도, 분화 정도, 괴사 정도로 구 분되는 세 가지 지표에 근거하여 나눌 수 있다. 유사분열 정 도에 따라 1 3점, 분화 정도에 따라 1 3점, 괴사 정도에 따라 0 2점을 부여하며 총 합산 점수가 2 3점일 경우 grade I(low grade), 4 5점일 경우 grade II(intermediate grade), 6 8점일 경우 grade III(high grade)로 평가한다. ${ }^{13)}$ 본 증례에서는 $\mathrm{mi}^{-}$ tosis $26 / 10 \mathrm{HPF}$ 로 3 점, 분화 정도 및 괴사 정도에서는 각 1점, 0점으로 intermediate grade에 해당하였다. 또한 면역조직화 학검사를 이용하면 진단에 도움이 되는데, 주로 vimentin, smooth muscle actin, calponin, fibronectin 등에 양성 소견 을 보이며 드물게 desmin에도 양성 소견을 보일 수 있다. ${ }^{17)}$

근섬유모세포 육종은 비정형핵과 콜라겐 및 유리질로 이 뤼진 섬유모세포 다발로 이루어져 있으며, 주변으로 광범위 하게 침습적인 성향을 띠는 특징이 있는데,10) 형태학적으로 섬 유모세포 및 평활근세포와 유사하므로 쉽게 오진할 수 있어 정확한 감별진단이 중요하다. ${ }^{47,8)}$ 악성 섬유조직구종의 경우 교차성 또는 나선형 배열을 보이며, 명백하게 다형태, 비정형 세포 모양을 보인다는 점에서 감별이 가능하다. ${ }^{4)}$ 섬유육종은 풍부한 다발성 세포 형태를 보이며 밀도 높고 단일화된 형태 의 세포들이 V자 배열(herringbone pattern)을 보인다는 특 징이 있다. ${ }^{4)}$ 평활근육종은 비교적 잘 구획되어진 경계면을 보이며, 주변 조직으로의 침습 성향이 약한 특징을 보인다.) 결절근막염은 세포밀도가 낮고 비교적 단일화된 세포구성을 보이며, 세포와 점액질, 섬유질이 혼재된 양상을 보인다. ${ }^{12)}$ 이 외에도 악성 말초신경초종이나 염증성 근섬유모세포 종양과 의 감별이 필요하다. ${ }^{4}$

근섬유모세포 육종의 치료는 일반적으로 외과적 광범위 절제이며, 경우에 따라 수술 후 방사선치료나 항암치료가 환 자의 예후를 호전시키는 데에 도움이 될 수 있다. ${ }^{4}$ 치료 방침 은 종양의 등급, 병변 부위와 크기, 환자의 나이, 인접조직으 로의 침범 여부 등을 고려하여 결정되어야 한다. ${ }^{5,10}$ 저등급의 경우 국소재발은 흔하지만 원격전이는 드문 반면 중등급이나 고등급의 경우 국소재발보다는 원격전이 위험도가 높다. ${ }^{45}$ 실제로 Fisher에 따르면 저등급의 39예 중에서 13예(33\%)에 서 국소재발, 3 예(8\%)에서 원격전이가 보고된 반면, 고등급의 22예 중에서는 7예(32\%)에서 국소재발, 15예(68\%)에서 원격 전이가 보고되었다. ${ }^{58)}$ 사이즈가 $10 \mathrm{~cm}$ 보다 크거나, 심부에 위 치하거나, high mitotic index(>10)를 보이거나, 조직의 부분 괴사가 동반되어 있으면 고등급일 가능성이 높다. ${ }^{14)}$ 만일 수 
술 후 고등급으로 판정되면 수술 후 방사선 치료가 추천되 며, 원격전이가 의심될 경우 항암 치료를 고려해야 한다. ${ }^{15)}$ 본 증례에서는 병변의 광범위 절제를 시행하였으며 2년간의 추 적 검사에서 재발하지 않았다.

최근까지 전 세계에서 보고된 두경부 영역의 중-고등급의 근섬유모세포 육종은 극히 드물어 아직 뚜렷한 치료 방침은 정립되어 있지 않다. 2009년 보고된 증례에서는 56세 여성의 혀 기저부에 발생한 중등급 근섬유모세포 육종에 대하여 외 과적 절제 시행 후 CT에서 국소 잔존 암 소견이 보여 방사선 치료를 병행하여 4년 동안 재발하지 않았다. ${ }^{1)}$ 2015년 보고된 또 다른 증례에서는 27세 남성의 우측 상악동에 발생한 중 등급 근섬유모세포 육종에 대하여 근치적 절제 시행 후 방사 선치료를 병행하여 2년 동안 재발하지 않았다. 이를 통해 중고등급의 근섬유모세포 육종의 치료에 있어 근치적 절제와 함께 방사선치료를 병행하는 것이 비교적 좋은 결과를 보인 다는 것을 알 수 있고, 향후 이와 관련한 지속적인 연구가 필 요할 것으로 보인다.

Ghosh 등ㄱ)에 따르면 전세계에서 보고된 55 증례의 저등 급 근섬유모세포 육종에서 볼 점막에 발생한 경우는 3건에 불과하며 문헌 고찰상 현재까지 국내에서 볼 점막에 발생한 근섬유모세포 육종이 보고된 경우는 없었다. 단순 외상으로 인한 볼 점막의 악성종양 발생 빈도는 비교적 낮기 때문에 볼 점막 종물을 주소로 내원한 환자에서 감별 진단 시 간과하기 쉽다. 볼 점막에서 무통성의 종물로 촉지되는 경우 섬유종(fibroma), 낭종(cyst), 피하의 지방종(lipoma) 등으로 진단되는 경우가 흔하나, 크기 증가 속도가 빠르거나 외상 후 조직의 회 복과정에서 발생한 종물인 경우 근섬유모세포 육종과 같은 악성종양의 가능성도 고려하여야 함을 본 증례는 시사하고 있다.

저자들은 볼 점막의 종물을 주소로 내원한 환자에서 문진 및 영상의학적 검사, 수술적 치료 및 조직 검사를 통해 볼 점 막에 발생한 근섬유모세포 육종을 치험하였기에 문헌 고찰 과 함께 보고하는 바이다.

\section{Acknowledgments}

This study was supported by a National Research Foundation of Korea (NRF) grant funded by the Korean government (NRF-2017 R1A2B4007657 to SH Lee)

\section{Author Contribution}

Conceptualization: Sang Hyuk Lee. Formal analysis: In Buhm Lee, Jin Lee. Funding acquisition: In Buhm Lee, Hye Soo Kim.
Methodology: In Buhm Lee, Jin Lee. Project administration: In Buhm Lee. Supervision: Jin Lee, Sang Hyuk Lee. Validation: In Buhm Lee, Hye Soo Kim. Visualization: In Buhm Lee, Jin Lee. Writing - original draft: In Buhm Lee. Writing — review \& editing: In Buhm Lee, Sang Hyuk Lee.

\section{ORCIDs}

Sang Hyuk Lee https://orcid.org/0000-0003-4412-3486

In Buhm Lee https://orcid.org/0000-0002-2254-8857

Jin Lee https://orcid.org/0000-0003-2264-8310

\section{REFERENCES}

1) Takácsi-Nagy Z, Muraközy G, Pogány P, Fodor J, Orosz Z. Myofibroblastic sarcoma of the base of tongue. Case report and review of the literature. Strahlenther Onkol 2009;185(3):198-201.

2) Baranov E, Hornick JL. Soft tissue special issue: fibroblastic and myofibroblastic neoplasms of the head and neck. Head Neck Pathol 2020;14(1):43-58.

3) Artopoulou II, Lemon JC, Clayman GL, Chambers MS. Stent fabrication for graft immobilization following wide surgical excision of myofibroblastic sarcoma of the buccal mucosa: A clinical report. J Prosthet Dent 2006;95(4):280-5.

4) Cai ZG, Pan CC, Yu DH, Feng ZZ, Ma L, Zhao Y, et al. Myofibroblastic sarcomas: A clinicopathologic analysis of 15 cases and review of literature. Int J Clin Exp Pathol 2016;9(2):1568-77.

5) Park KR, Jang HW, Won JH, Kim HS, Cha IH, Kim HJ. Myofibroblastic sarcoma of the mandible: A case report. J Korean Assoc Oral Maxillofac Surg 2012;38(4):240-4.

6) Fisher C. Myofibrosarcoma. Virchows Arch 2004;445(3):215-23.

7) Ghosh A, Bandopadhyay A, Sarkar R. Low-grade myofibroblastic sarcoma of maxillary sinus and buccal mucosa: Two rare cases and review of the literature. Indian J Pathol Microbiol 2019;62(1):119-21.

8) Fisher C. Myofibroblastic malignancies. Adv Anat Pathol 2004;11(4): 190-201.

9) Takahama A Jr, Nascimento AG, Brum MC, Vargas PA, Lopes MA. Low-grade myofibroblastic sarcoma of the parapharyngeal space. Int J Oral Maxillofac Surg 2006;35(10):965-8.

10) Mentzel T, Dry S, Katenkamp D, Fletcher CD. Low-grade myofibroblastic sarcoma: Analysis of 18 cases in the spectrum of myofibroblastic tumors. Am J Surg Pathol 1998;22(10):1228-38.

11) Wang L, Li LX, Chen DQ, Yang L, Li SK, Cheng C. Low-grade Myofibroblastic sarcoma: Clinical and imaging findings. BMC Med Imaging 2019;19(1):36.

12) Zhang S, Ma Y, Ma T, Wang Z. Low-grade myofibroblastic sarcoma of the orbit: A case report and literature review. Medicine (Baltimore) 2017;96(51):e9172.

13) Coindre JM. Grading of soft tissue sarcomas: Review and update. Arch Pathol Lab Med 2006;130(10):1448-53.

14) Khoury JD, Coffin CM, Spunt SL, Anderson JR, Meyer WH, Parham DM. Grading of nonrhabdomyosarcoma soft tissue sarcoma in children and adolescents: A comparison of parameters used for the Fédération Nationale des Centers de Lutte Contre le Cancer and Pediatric Oncology Group systems. Cancer 2010;116(9):2266-74.

15) Kawaguchi N, Ahmed AR, Matsumoto S, Manabe J, Matsushita Y. The concept of curative margin in surgery for bone and soft tissue sarcoma. Clin Orthop Relat Res 2004;419:165-72. 